\title{
Quality Attributes and Shelf Life of High-Pressure Preserved Beef as Affected by Pre-treatment Conditions
}

\author{
Belén Giménez $^{1}$ • Natalia Graiver ${ }^{1}$ • Alicia Califano ${ }^{1}$ • Noemí Zaritzky ${ }^{1,2}$
}

Received: 14 February 2017 / Accepted: 20 July 2017 / Published online: 5 August 2017

(C) Springer Science+Business Media, LLC 2017

\begin{abstract}
This study analyzed the effects of high hydrostatic pressure (HHP) and composition of the pre-treatment immersion step, on quality attributes (color and lipid oxidation) and shelf life based on microbial counts of a beef product, during cold storage at $0{ }^{\circ} \mathrm{C}$. Meat slices were immersed in a preservative solution containing sodium nitrite, ascorbic acid, and two different concentrations of $\mathrm{NaCl}(30$ and $60 \mathrm{~g} / \mathrm{L})$; HHP of 400 and $600 \mathrm{MPa}$ were applied. Results were compared with those of an untreated beef control. Color parameters of the HHP-treated beef were visually acceptable $\left(\mathrm{a}^{*}>14\right)$ in all tested cases, although they were affected by $\mathrm{NaCl}$ concentration and the applied pressure. HHP increased TBARS index, observing higher values at 600 than at $400 \mathrm{MPa}$; samples immersed in the solution containing $30 \mathrm{~g} / \mathrm{L} \mathrm{NaCl}$ presented higher TBARS values. However, in all cases, they remained below the detection limit of rancid meat products $(<1 \mathrm{mg}$ $\mathrm{MDA} / \mathrm{kg}$ ). Beef samples immersed in the solution with the highest concentration of $\mathrm{NaCl}(60 \mathrm{~g} / \mathrm{L})$ and subjected to 400 or $600 \mathrm{MPa}$ maintained their microbial stability over 5 and
\end{abstract}

Natalia Graiver

nataliagraiver@hotmail.com

Belén Giménez

belengimenez@live.com.ar

Alicia Califano

anc@quimica.unlp.edu.ar

Noemí Zaritzky

zaritzkynoemi@gmail.com

1 Centro de Investigación y Desarrollo en Criotecnología de Alimentos (CIDCA), CONICET - UNLP- CICPBA, 47 y 116, 1900 La Plata, Argentina

2 Fac. de Ingeniería, Depto. de Ing. Química, UNLP. 47 y 1, 1900 La Plata, Argentina
6 weeks, respectively, at $0{ }^{\circ} \mathrm{C}$; these shelf life values were higher than those observed in the samples treated with $30 \mathrm{~g} /$ $\mathrm{L} \mathrm{NaCl}$.

Keywords Beef $\cdot$ High hydrostatic pressure $\cdot$ Lipid oxidation $\cdot$ Salt pre-treatment $\cdot$ Microbial growth

\section{Introduction}

High-pressure (HP) processing, also known as high hydrostatic pressure (HHP), or ultra high-pressure (UHP) processing, is an alternative technology for food preservation that subjects liquid or solid foods to pressures between 50 and $1000 \mathrm{MPa}$ (Hogan et al. 2005). The most common commercial application of this technology, which is also known as "cold pasteurization," uses pressures higher than $300 \mathrm{MPa}$ for short periods in packaged foods, achieving a reduction in the microbial counts similar to the traditional thermal pasteurization, which eliminates vegetative pathogens (Listeria monocytogenes and Salmonella) and inactivate certain enzymes. According to literature, significant antibacterial effects are observed using HHP treatments ranging between 300 and $600 \mathrm{MPa}$ (Tao et al. 2014).

The HHP technology can also be applied to develop new products (reduced in salt, fat) and for the optimization of conventional food processes such as meat marinating and tenderization. HHP treatment can alter the structure of the meat, color, and levels of lipid oxidation (Carlez et al. 1995; Ueno et al. 1999 and Ma et al. 2007). Different studies reported that by subjecting beef samples to HHP, the characteristic red color was lost, resulting in a meat product with an undesirable pale coloration (whitening effect) that is unacceptable for consumers. Jung et al. (2003) carried out pressure treatments (50-600 MPa, $10^{\circ} \mathrm{C}, 5 \mathrm{~min}$ ) on raw beef muscle and observed 
an increase in beef lightness $\left(\mathrm{L}^{*}\right)$ at pressures higher than $200 \mathrm{MPa}$. Changes in the chromatic parameters of fresh beef treated by HHP such as increases in lightness $\left(\mathrm{L}^{*}\right)$ and decreases in redness $\left(\mathrm{a}^{*}\right)$ were reported by Carlez et al. (1995), Cheftel (1995), Bajovic et al. (2012), and Tao et al. (2014).

Cheah and Ledward (1996) reported that treatments above 300-400 MPa produced protein denaturation; changes in sarcoplasmic and myofibrillar proteins induce meat surface alterations and therefore color modifications. Goutefongea et al. (1995) explained that the increasing in lightness is due to globin denaturation with porphyric ring disruption or release under the action of pressure.

High pressure in fresh beef leads to discoloration that can be attributed to denaturation of myoglobin and/or to heme displacement or loss of the heme-iron (Szerman et al. 2011). The hydrophobic interaction is of paramount importance for the stabilization of many biological components and plays a decisive role in the folding of proteins. Grigera and McCarthy (2010) reported that there is a direct correlation between the denaturation of the proteins and the loss of hydrophobic interactions as a direct consequence of the changes in water structure. At high pressure, the hydrophobic effect, the main factor in maintaining native structure, decays. Under HHP, the exposure of the hydrophobic core of a globular protein such as myoglobin to the solvent results in a decrease of the volume of the system. This is because water in the vicinity of nonpolar groups shows a much higher compressibility than that of hydrophilic hydration and bulk water. Then the unfolding/ denaturing process will be favored at high pressure. Two phenomena are present under high pressure: The weakening of hydrophobic interaction as a driving force to start the process and a decrease in the volume of the system as the hydrophobic core is exposed.

In order to minimize the whitening effect in beef, a previous dipping process in a solution containing chemical preservatives allows the formation of nitrosomyoglobin maintaining a suitable color at the product surface (Ferrini et al. 2012 and Giménez et al. 2015). Nitrosomyoglobin is a more stable pigment at high pressures due to its resistance to oxidation compared with myoglobin and oxymyoglobin (Rubio et al. 2007); therefore, it is essential to carry out a previous step of immersion in a preservative solution, before applying the high pressures.

Giménez et al. (2015) tested different formulations of preservative solutions to optimize its composition in order to maintain the color attributes in beef submitted to HHP, minimizing the concentration of sodium nitrite by using desirability functions. Concentrations ranging between 0.52 and $1.10 \mathrm{~g}$ $\mathrm{NaNO}_{2} / \mathrm{L}$ and $0-10 \mathrm{~g}$ ascorbic acid/L and $60 \mathrm{~g} / \mathrm{L} \mathrm{NaCl}$ were tested. In that work, the authors reported that the presence of ascorbic acid in the preservative solution containing sodium nitrite and sodium chloride was essential to obtain the desired color in the meat after hydrostatic pressure treatment. The optimized preservative solution contained however a high concentration of sodium chloride that affected the taste. A sensory analysis performed with an untrained panel evidenced that the product immersed in $60 \mathrm{~g} / \mathrm{L} \mathrm{NaCl}$ was quite salty, affecting its palatability.

The concentration of sodium chloride in the immersion solution affects the quality and stability of meats submitted to high pressures (Duranton et al. 2012). Salt reduction in meat products is one of the strong tendencies of consumers to demand minimally processed and healthy meat products due to the progressive increase in the incidence of cardiovascular diseases in the population. Excessive sodium intake is associated with an increase in blood pressure, which is a major cause of cardiovascular diseases. It has been estimated that $62 \%$ of strokes and $49 \%$ of coronary heart diseases are caused by high blood pressure (He and MacGregor 2010). Sodium improves the sensory properties of foods, by increasing saltiness, decreasing bitterness, and increasing sweetness and other congruent flavor effects (Keast and Breslin 2002). Reducing sodium chloride level may affect texture and other quality characteristics including, moisture level, fat content, and $\mathrm{pH}$ (Dotsch et al. 2009). Sodium nitrite contributes to the development of the typical pink color of cured products and their distinctive flavor. In combination with salt, nitrite also inhibits food spoilage bacteria (Duranton et al. 2012).

The reduction of salt and nitrite is problematic because of their technological properties; therefore, some adjustments are required to maintain the safety and quality of the product (Duranton et al. 2012). In this regard, the analysis of the effect of lowering sodium chloride content in meat products subjected to HHP is of great interest.

Lipid oxidation leads to rancidity and off flavors; it is an important parameter contributing to the sensory quality of the meat influencing its acceptability (Gray et al. 1996). The HHP process, especially when the applied pressures are higher than $500 \mathrm{MPa}$, could initiate lipid oxidation in meat, inducing the alteration of fatty acid composition. Some authors have reported increased levels of lipid oxidation in the meat undergoing HHP (Cheah and Ledward 1996; Ma et al. 2007). Mor-Mur (2010), associated oxidation of fatty acids to the release of pro-oxidant metals such as heme iron (by denaturation of myoglobin), or copper when cells are damaged by effect of pressure. The intensity of oxidation depends on the treatment parameters prior to food processing. Beltran et al. (2003) found significant differences between the values of thiobarbituric acid reactive substances (TBARS) index, commonly used to quantify the oxidation, among different samples of meat subjected to HHP.

The objective of this work was to analyze the influence of the pre-treatment immersion conditions and especially the sodium chloride concentration and the applied pressures (400 and $600 \mathrm{MPa}$ ), on color, lipid oxidation, microbial growth, and shelf life of high pressure treated beef during cold storage at $0{ }^{\circ} \mathrm{C}$. 


\section{Materials and Methods}

\section{Raw Materials}

Beef muscles were obtained under controlled conditions from the local market. The commercial cut used was top inside round (top side, adductor femoris and semimembranosus muscles); the meat were removed after $48 \mathrm{~h}$ post-mortem and the visible fat was separated.

\section{Characterization of Raw Material}

The measurement of $\mathrm{pH}$ was carried out in triplicates using a spear tip glass electrode (Van London-pHoenix Company, Model CLO1502, Houston, USA) on a pH meter (Hach Sension $\mathrm{pH}$ 3, Loveland, USA).

The water activity of fresh meat was determined using Aqua Lab Series 4 TEV Instrument (USA) calibrated with a solution of $\mathrm{NaCl}$ (aw $=0.753 \pm 0.002$ ) and double distilled water $(\mathrm{aw}=1)$. The measurements of aw are based on the dew point determination and were performed at $25^{\circ} \mathrm{C}$ in triplicates.

Moisture, ash, protein, and lipid contents were determined in fresh beef (control sample) according to AOAC methods 24.002, 24.009, 24.027, and 24.005, respectively (AOAC 1980) in duplicate. Fat content was determined by Soxhlet method, using ethyl ether as extraction solvent on samples previously treated with anhydrous sodium sulfate $\left(\mathrm{Na}_{2} \mathrm{SO}_{4}\right)$. $\mathrm{Na}_{2} \mathrm{SO}_{4}$ was mixed with the minced meat prior to the extraction procedure, to remove moisture, and to avoid emulsion formation.

\section{Chemical Pre-treatment and Packaging}

The general procedure consisted of: (a) cutting the meat samples in cylindrical sections ( $3 \mathrm{~mm}$ thickness and $6 \mathrm{~cm}$ diameter); (b) each individual sample was immersed in $150 \mathrm{~mL}$ of preservative solution during $2.5 \mathrm{~h}$; (c) vacuum packaging of the samples in Cryovac BB4L films (Sealed Air Co., Buenos Aires, Argentina, $\mathrm{PO}_{2}: 35\left(\mathrm{~cm}^{3} / \mathrm{m}^{2}\right.$ daybar) at $23{ }^{\circ} \mathrm{C}$; (d) high pressure treatment. Based on previous results (Giménez et al. 2015), solutions were formulated with $0.62 \mathrm{~g} / \mathrm{L} \mathrm{NaNO}_{2}, 8.5 \mathrm{~g}$ ascorbic acid/L, and two levels of sodium chloride: solution $\mathrm{S} 1$ contained $30 \mathrm{~g} \mathrm{NaCl} / \mathrm{L}$ and solution $\mathrm{S} 2,60 \mathrm{~g} \mathrm{NaCl} / \mathrm{L}$.

\section{HHP Treatment}

HHP treatment was carried out in INTA Laboratory, Castelar, Argentina, using a Stansted Fluid Power Equipment, model FPG9400:922 (UK) with a cylindrical vessel (2 1 capacity). The maximum working pressure of the equipment is $900 \mathrm{MPa}$. The pressurization rate was $300 \mathrm{MPa} / \mathrm{min}$, and depressurization was conducted instantaneously.
Experiments were carried out at two pressures: 400 and $600 \mathrm{MPa}$ and at a temperature of $20 \pm 5^{\circ} \mathrm{C}$; the samples were maintained at the working pressures for $5 \mathrm{~min}$. In all cases, control samples of fresh beef (untreated beef), that were not subjected to the immersion step and to HHP, were also analyzed. These pressures were selected due to the antimicrobial effect produced by HHP treatment in the range 300 to $600 \mathrm{MPa}$ (Tao et al. 2014).

\section{Refrigerated Storage}

All the samples were stored at $0{ }^{\circ} \mathrm{C}$, in order to evaluate the shelf life of the beef product during refrigerated storage. Throughout the storage period, color, lipid oxidation, and microbial counts were measured weekly for 45 days.

\section{Chloride and Nitrate Analytical Determinations}

To measure the amount of $\mathrm{NaCl}$ present in the tissue after the immersion period, the chloride content was determined. Meat tissue was homogenized with bi-distilled water at $90{ }^{\circ} \mathrm{C}$; the suspension was stirred, diluted with water, and filtered. A previously calibrated ion-selective electrode (Cole-Parmer 27502-12) was used for chloride measurement. Similar extraction procedures were followed for nitrite determination using Hach kit Nitriver 3, (method 371$)$ as reported by Graiver et al. (2006). These determinations were made in duplicate.

\section{Instrumental Color Measurements}

The surface color of beef samples was determined using a Minolta colorimeter CR 400 Series (Konica, Osaka, Japan). The Standard illuminant $C$ that corresponds to average daylight (not including ultraviolet wavelength region) with a correlated color temperature of $6774 \mathrm{~K}$, and the two-degree standard observer angle (that closely matches CIE-1931 standard observer) were used. The CIEL*a*b* scale was used, and lightness $\left(\mathrm{L}^{*}\right)$ and chromaticity parameters: $\mathrm{a}^{*}$ (red-green) and $b^{*}$ (yellow-blue) were measured. Measurements were performed weekly on three samples of meat, doing six measurements for each sample. The total color difference $\left(\Delta \mathrm{E}^{*}\right)$ was determined as an estimate of color changes according to:

$$
\begin{aligned}
\Delta \mathrm{E}^{*} & =\left[\left(\mathrm{L}^{*}-\mathrm{L}_{\text {ref }}^{*}\right)^{2}+\left(\mathrm{a}^{*}-\mathrm{a}_{\text {ref }}^{*}\right)^{2}+\left(\mathrm{b}^{*}-\mathrm{b}_{\text {ref }}^{*}\right)^{2}\right]^{1 / 2} \\
& =\left[\left(\Delta \mathrm{L}^{*}\right)^{2}+\left(\Delta \mathrm{a}^{*}\right)^{2}+\left(\Delta \mathrm{b}^{*}\right)^{2}\right]^{1 / 2}
\end{aligned}
$$

In $\Delta \mathrm{E}^{*}$ calculation, the color values used as reference correspond to untreated fresh beef samples (time zero, without storage). 


\section{Microbiological Analysis}

To determine the shelf life during refrigerated storage at $0{ }^{\circ} \mathrm{C}$, microbial counts were performed at different times on the samples immersed in the preservative solution and pressure treated at 400 or $600 \mathrm{MPa}$ and on meat samples without any treatment (control).

Approximately $10 \mathrm{~g}$ meat samples were taken from each bag, diluted with $90 \mathrm{~mL}$ of $0.1 \mathrm{~g} / 100 \mathrm{~mL}$ peptone solution, and homogenized in a Stomacher 400 (Seward, USA) for $120 \mathrm{~s}$ at the maximum speed. Serial dilutions were performed using tubes with peptone $0.1 \mathrm{~g} / 100 \mathrm{~mL}$ and samples were plated on suitable culture media. The colony-forming units $(\mathrm{CFU}) / \mathrm{g}$ beef were determined after incubation.

The samples were tested for total aerobic mesophilic microorganisms (Plate Count Agar (PCA), $30{ }^{\circ} \mathrm{C}, 2$ days), total psychrotrophic aerobic (Plate Count Agar (PCA), $4{ }^{\circ} \mathrm{C}$, 7 days), enterobacteriaceae (Violet Red Bile Agar (VRBA), $37^{\circ} \mathrm{C}, 24 \mathrm{~h}$ ), lactic acid bacteria (MRS, $30^{\circ} \mathrm{C}, 2$ days), yeasts, and molds (Chloramphenicol Glucose Agar (YGC), 5 days, $30{ }^{\circ} \mathrm{C}$ ). These determinations were made weekly in duplicate.

\section{Lipid Oxidation}

Lipid oxidation was evaluated by the method of thiobarbituric acid (TBA) which reports thiobarbituric acid reactive substances (TBARS). TBA determinations were performed on trichloroacetic acid (TCA) extracts from $2 \mathrm{~g}$ of minced meat. Two independent extracts were obtained for each sample and subjected to the TBA reaction $\left(30 \mathrm{~min}, 70{ }^{\circ} \mathrm{C}\right.$ ) (Botsoglou et al. 1994).

Oxidation was measured in the samples dipped in the preservative solutions (S1 and S2) and then submitted to HHP treatments and on meat samples without any treatment (control) during refrigerated storage at $0{ }^{\circ} \mathrm{C}$. TBA number was calculated as follows:

$$
\begin{aligned}
& \text { TBA number (mg MDA/kg meat) } \\
& =\frac{\mathrm{Abs} * M * V a * V e^{*} 1000}{\varepsilon^{*} d^{*} m}
\end{aligned}
$$

where MDA: malondialdehyde; Abs: absorbance at $532 \mathrm{~nm}$; : molecular weight of MDA (72 g); Va: sample volume (2 mL); $V e$ : extract volume $(16 \mathrm{~mL})$; $\varepsilon$ : molar extinction coefficient $\left(1.56 \times 10^{5} \mathrm{M}^{-1}\right) ; d$ : optical path $(\mathrm{cm}) ; m$ : meat sample weight.

\section{Statistical Analyses}

Statistical analyses were done using SYSTAT version 10.0 (SYSTAT Inc., USA, 1996). Analysis of variance (ANOVA) was applied to determine significant effects. Least significant difference tests (LSD) were used to perform pair-wise comparisons between means. Differences in means and $F$ test were considered statistically significant when $P<0.05$.

\section{Results and Discussion}

\section{Analysis of Percentage Composition of Beef Tissue, pH, and aw}

Beef chemical composition was: protein $21.6 \pm 0.7$, lipids $5.75 \pm 0.07$, ash $1.10 \pm 0.01$, water $72.65 \pm 0.8$ expressed as $\mathrm{g} / 100 \mathrm{~g}$ of beef \pm standard deviation, while carbohydrates were obtained by difference between all the components $0.10 \pm 0.01$. The aw was $0.985 \pm 0.001 ; \mathrm{pH}$ ranged between 5.4 and 5.7. These data are in agreement with the reported by the USDA (2016): protein 20.61, lipids 6.01, ash 1.03, water 72.48 , and carbohydrates 0.00 expressed as $\mathrm{g} / 100 \mathrm{~g}$ of beef.

\section{Determination of $\mathrm{NaCl}$ and $\mathrm{NaNO}_{2}$ Residual Concentrations in Meat Tissue}

The concentrations of sodium nitrite and sodium chloride in beef samples after treatment were $0.0026 \pm 0.0006 \mathrm{~g} \mathrm{NaNO}_{2} /$ $100 \mathrm{~g}$ meat tissue and $1.95 \pm 0.72 \mathrm{~g} \mathrm{NaCl} / 100 \mathrm{~g}$ meat tissue for the samples immersed in Solution S1. For samples immersed in $\mathrm{S} 2$, the values were $0.0041 \pm 0.0003 \mathrm{~g} \mathrm{NaNO}_{2} / 100 \mathrm{~g}$ meat tissue and $5.24 \pm 0.53 \mathrm{~g} \mathrm{NaCl} / 100 \mathrm{~g}$ meat tissue. These values were into acceptable ranges, in compliance with what is established in the current legislation. According to USDAFSIS (1999), the use of $\mathrm{NaNO}_{2}, \mathrm{KNO}_{3}$, or their combinations must not exceed $200 \mathrm{ppm}(0.2 \mathrm{~g} / \mathrm{kg})$ expressed as $\mathrm{NaNO}_{2}$ in the final product. FAO (1991) established that the maximum amount of nitrite permitted in finished meat products is usually $200 \mathrm{mg}$ per $\mathrm{kg}$, or may be less depending on the type of meat. The current public health recommendation in most countries is to reduce salt intake from about 9-12 to 5-6 g/ day (He et al. 2011). As shown in the results, the samples immersed in $\mathrm{S} 2$ solution containing the highest concentration of $\mathrm{NaCl}$ showed also a higher residual concentration of sodium nitrite; this result can be attributed to the higher effective diffusivity of sodium nitrite with increasing concentrations of $\mathrm{NaCl}$ in the dipping solution (Graiver et al. 2006).

\section{Color}

The visual aspect is a critical parameter in the purchasing and consumption of meat products. Initial average color parameters of untreated fresh samples were $\mathrm{a}^{*}=20.28 \pm 0.25$, and $\mathrm{L}^{*}=39.59 \pm 0.29$; changes in these parameters during refrigerated storage at $0{ }^{\circ} \mathrm{C}$ are shown in Table 1 . Data were obtained during 2 weeks because control samples lost their microbiological quality during the second week. Parameter $\mathrm{b} *$ did 
Table 1 Color parameters $\mathrm{L}^{*}, \mathrm{a}^{*}, \mathrm{~b}^{*}$ throughout the refrigerated storage at $0{ }^{\circ} \mathrm{C}$ of fresh meat samples (control)

\begin{tabular}{llll}
\hline Time (weeks) & $L^{*}$ & $a^{*}$ & $b^{*}$ \\
\hline 0 & $39.59 \pm 0.29^{\mathrm{a}}$ & $20.28 \pm 0.25^{\mathrm{a}}$ & $11.61 \pm 0.76^{\mathrm{a}}$ \\
1 & $44.89 \pm 0.77^{\mathrm{b}}$ & $21.52 \pm 1.45^{\mathrm{a}, \mathrm{b}}$ & $12.62 \pm 0.86^{\mathrm{a}}$ \\
$2^{\mathrm{a}}$ & $45.22 \pm 1.13^{\mathrm{b}}$ & $22.42 \pm 0.24^{\mathrm{b}}$ & $12.38 \pm 0.23^{\mathrm{a}}$ \\
\hline
\end{tabular}

Different letters in the same column indicate significant differences $(P<0.05)$; values are means $\pm \mathrm{SD}$

${ }^{a}$ Control beef samples lost their microbiological quality during the second week of storage

not change significantly along the storage period $(P>0.05)$ leading to an average value of $12.20 \pm 0.53$. In the case of samples previously immersed in saline solutions and then HHP treated, $\Delta \mathrm{E}^{*}$ depended significantly $(P<0.05)$ on the composition of the immersion solution and pressure, as shown in Table $2 . \Delta \mathrm{E}^{*}$ was not significantly influenced $(P>0.05)$ by storage time in samples submitted to $600 \mathrm{MPa}$. However, $\Delta \mathrm{E}^{*}$ changed slightly during refrigerated storage in samples submitted to $400 \mathrm{MPa}$; in this case, during 6 weeks storage time at $0{ }^{\circ} \mathrm{C}, \Delta \mathrm{E}^{*}$ values increased from 11.70 to 12.89 for $\mathrm{S} 1$ and from 9.70 to 11.59 for $\mathrm{S} 2$.

Table 2 shows that $\Delta \mathrm{E}^{*}$ increased with the applied pressure and with the decrease of $\mathrm{NaCl}$ concentration in the dipping solution. In order to interpret better $\Delta \mathrm{E}^{*}$ results, it is convenient to analyze the individual color parameters $\left(\mathrm{L}^{*}, \mathrm{a}^{*}, \mathrm{~b}^{*}\right)$.

The value of $b^{*}$ was not considered significant to represent color variations in the samples therefore results of $\mathrm{L}^{*}$ and $\mathrm{a}^{*}$ are discussed.

Lightness values $\left(\mathrm{L}^{*}\right)$ in beef samples previously immersed in S1 and S2 and subjected to both pressure levels 400 and $600 \mathrm{MPa}$ are shown in Table 3. It can be observed that the values of $L^{*}$ in Table 3 are higher than that of the fresh control beef samples (Table 1) but lower than in samples subjected to high pressure without a previous chemical treatment $\left(\mathrm{L}^{*}=60\right.$ at $\left.600 \mathrm{MPa}\right)$ according to a previous work (Giménez et al. 2015).

Analysis of variance showed that for both tested pressures, the samples immersed in $\mathrm{S} 2(60 \mathrm{~g} \mathrm{NaCl} / \mathrm{L})$ had lower $\mathrm{L}^{*}$ values compared to those immersed in $\mathrm{S} 1(30 \mathrm{~g} \mathrm{NaCl} / \mathrm{L})$. Samples subjected to $400 \mathrm{MPa}$ had lower values of $\mathrm{L}^{*}$ than those subjected to $600 \mathrm{MPa}$. L* was not significantly influenced $(P>0.05)$ by storage time in samples submitted to $600 \mathrm{MPa}$, although in the case of $400 \mathrm{MPa} \mathrm{L}^{*}$ changed slightly during refrigerated storage.

Parameter a* depended significantly $(P<0.05)$ on the composition of the immersion solution, pressure and storage time as shown in Table 4. Samples treated at $400 \mathrm{MPa}$ had in general higher a ${ }^{*}$ values than those subjected to $600 \mathrm{MPa}$.

Samples immersed in S2 had higher redness $\left(>\mathrm{a}^{*}\right)$ than samples treated with $\mathrm{S} 1$. This result combined with a lower $\mathrm{L}^{*}$ can be attributed to the higher effective diffusivity of $\mathrm{NaNO}_{2}$ with increasing concentrations of $\mathrm{NaCl}$ in the dipping solution (Graiver et al. 2006), improving color stability due to the formation of a higher nitrosomyoglobin concentration.

Similar results were reported by Bak et al. (2012) who studied the effect of HHP on the color of minced cured ham.

Changes of both parameters $\left(\mathrm{a}^{*}\right.$ and $\left.\mathrm{L}^{*}\right)$ with the pressure level can be attributed to the effect of high pressure on the denaturation of sarcoplasmic proteins (mainly myoglobin) with porphyric ring disruption or release under the action of pressure and modification of the composition of the sarcoplasmic protein fraction (Marcos et al. 2010, Grigera and McCarthy 2010, Szerman et al. 2011).

During refrigerated storage of the treated samples, $a^{*}$ slightly decreased; this result can be attributed to changes in nitrosomyoglobin caused by globin denaturation and/or heme displacement or release (Cheftel and Culiol 1997, Andrés
Table 2 Effect of HHP pressures (400 and $600 \mathrm{MPa}$ ) and sodium chloride concentration in the dipping solution $(\mathrm{S} 1: 30 \mathrm{~g} \mathrm{NaCl} /$ $\mathrm{L}$ and $\mathrm{S} 2: 60 \mathrm{~g} \mathrm{NaCl} / \mathrm{L}$ ) on $\Delta \mathrm{E}^{*}$ during refrigerated storage at $0{ }^{\circ} \mathrm{C}$ of beef samples

\begin{tabular}{|c|c|c|c|c|}
\hline \multirow{2}{*}{$\begin{array}{l}\Delta \mathrm{E}^{*} \\
\text { Time } \\
\text { (weeks) }\end{array}$} & \multicolumn{2}{|l|}{$400 \mathrm{MPa}$} & \multicolumn{2}{|l|}{$600 \mathrm{MPa}$} \\
\hline & $\mathrm{S} 1$ & $\mathrm{~S} 2$ & $\mathrm{~S} 1$ & $\mathrm{~S} 2$ \\
\hline 0 & $11.70 \pm 1.16^{\mathrm{a}, \mathrm{A}, \mathrm{B}}$ & $9.70 \pm 1.40^{\mathrm{b}, \mathrm{c}, \mathrm{A}}$ & $16.54 \pm 2.50^{\mathrm{a}, \mathrm{C}}$ & $12.92 \pm 1.56^{\mathrm{a}, \mathrm{B}}$ \\
\hline 1 & $16.51 \pm 1.75^{\mathrm{c}, \mathrm{C}}$ & $9.16 \pm 1.32^{\mathrm{a}, \mathrm{b}, \mathrm{A}}$ & $17.23 \pm 1.14^{\mathrm{a}, \mathrm{C}}$ & $13.85 \pm 1.48^{\mathrm{a}, \mathrm{B}}$ \\
\hline 2 & $10.58 \pm 0.57^{\mathrm{a}, \mathrm{b}, \mathrm{A}}$ & $10.33 \pm 1.81^{\mathrm{b}, \mathrm{c}, \mathrm{d}, \mathrm{A}}$ & $16.84 \pm 2.17^{\mathrm{a}, \mathrm{C}}$ & $14.07 \pm 1.03^{\mathrm{a}, \mathrm{B}}$ \\
\hline 3 & $12.81 \pm 2.05^{\mathrm{a}, \mathrm{b} \mathrm{A}, \mathrm{B}}$ & $10.80 \pm 0.38^{\mathrm{c}, \mathrm{d} A}$ & $17.32 \pm 1.83^{\mathrm{a}, \mathrm{C}}$ & $14.09 \pm 0.85^{\mathrm{a}, \mathrm{B}}$ \\
\hline 4 & $14.44 \pm 2.19^{\mathrm{b}, \mathrm{c}, \mathrm{A}, \mathrm{B}}$ & $11.43 \pm 0.20^{\mathrm{d}, \mathrm{A}}$ & $17.54 \pm 3.57^{\mathrm{a}, \mathrm{B}}$ & $14.18 \pm 1.65^{\mathrm{a}, \mathrm{A}, \mathrm{B}}$ \\
\hline 5 & $14.08 \pm 3.11^{\mathrm{b}, \mathrm{c}, \mathrm{B}}$ & $7.96 \pm 0.81^{\mathrm{a}, \mathrm{A}}$ & $15.69 \pm 1.89^{\mathrm{a}, \mathrm{B}}$ & $12.08 \pm 3.07^{\mathrm{a}, \mathrm{B}}$ \\
\hline 6 & $12.89 \pm 2.29^{\mathrm{a}, \mathrm{b}, \mathrm{A}}$ & $11.59 \pm 0.36^{\mathrm{d}, \mathrm{A}}$ & $16.65 \pm 3.72^{\mathrm{a}, \mathrm{B}}$ & $13.86 \pm 0.90^{\mathrm{a}, \mathrm{A}, \mathrm{B}}$ \\
\hline
\end{tabular}

Values are means $\pm \mathrm{SD}$

a-d: average values with different letters in the same column are different $(p<0.05)$

A-C: average values with different letters in the same row are different $(p<0.05)$ 
Table 3 Effect of HHP pressures (400 and $600 \mathrm{MPa}$ ) and sodium chloride concentration in the dipping solution ( $\mathrm{S} 1: 30 \mathrm{~g} \mathrm{NaCl} /$ $\mathrm{L}$ and $\mathrm{S} 2: 60 \mathrm{~g} \mathrm{NaCl} / \mathrm{L}$ ) on color parameter $\mathrm{L}^{*}$ during refrigerated storage at $0{ }^{\circ} \mathrm{C}$ of beef samples

\begin{tabular}{llllll}
\hline $\mathrm{L}^{*}$ & \multicolumn{2}{l}{$400 \mathrm{MPa}$} & & \multicolumn{2}{l}{$600 \mathrm{MPa}$} \\
\cline { 2 - 3 } \cline { 5 - 6 } \begin{tabular}{lllll} 
Time \\
\cline { 5 - 6 } (weeks)
\end{tabular} & $\mathrm{S} 1$ & $\mathrm{~S} 2$ & & $\mathrm{~S} 1$ & $\mathrm{~S} 2$ \\
\hline 0 & & & & \\
\hline & $51.19 \pm 1.14^{\mathrm{a}, \mathrm{b}, \mathrm{A}, \mathrm{B}}$ & $48.75 \pm 1.77^{\mathrm{b}, \mathrm{c}, \mathrm{A}}$ & & $56.01 \pm 2.40^{\mathrm{a}, \mathrm{C}}$ & $52.27 \pm 1.59^{\mathrm{a}, \mathrm{B}}$ \\
2 & $55.08 \pm 0.33^{\mathrm{c}, \mathrm{B}, \mathrm{C}}$ & $47.92 \pm 1.62^{\mathrm{a}, \mathrm{b}, \mathrm{A}}$ & & $56.40 \pm 0.85^{\mathrm{a}, \mathrm{C}}$ & $53.14 \pm 1.49^{\mathrm{a}, \mathrm{B}}$ \\
3 & $49.92 \pm 0.48^{\mathrm{a}, \mathrm{A}}$ & $49.38 \pm 1.74^{\mathrm{b}, \mathrm{c}, \mathrm{d}, \mathrm{A}}$ & & $56.15 \pm 2.09^{\mathrm{a}, \mathrm{C}}$ & $53.01 \pm 1.00^{\mathrm{a}, \mathrm{B}}$ \\
4 & $52.24 \pm 2.16^{\mathrm{a}, \mathrm{b} A, \mathrm{~B}}$ & $50.21 \pm 0.45^{\mathrm{c}, \mathrm{d}, \mathrm{A}}$ & & $56.22 \pm 1.68^{\mathrm{a}, \mathrm{C}}$ & $53.41 \pm 0.83^{\mathrm{a}, \mathrm{B}}$ \\
5 & $53.82 \pm 2.17^{\mathrm{b}, \mathrm{c}, \mathrm{A}, \mathrm{B}}$ & $50.68 \pm 0.29^{\mathrm{d}, \mathrm{B}}$ & & $55.95 \pm 4.01^{\mathrm{a}, \mathrm{A}}$ & $53.09 \pm 1.78^{\mathrm{a}, \mathrm{A}, \mathrm{B}}$ \\
6 & $53.55 \pm 3.19^{\mathrm{b}, \mathrm{c}, \mathrm{B}}$ & $46.56 \pm 0.96^{\mathrm{a}, \mathrm{A}}$ & & $54.73 \pm 1.55^{\mathrm{a}, \mathrm{B}}$ & $51.11 \pm 3.18^{\mathrm{a}, \mathrm{B}}$ \\
\hline
\end{tabular}

Values are means $\pm \mathrm{SD}$

a-d: average values with different letters in the same column are different $(p<0.05)$

A-C: average values with different letters in the same row are different $(p<0.05)$ et al. 2004 and Bak et al. 2012). Another reason could be the oxidation of ferrous myoglobin to ferric metmyoglobin (Andrés et al. 2004; Campus et al. 2008), although the latter effect could be minimized by the formation of nitrosomyoglobin. Jung et al. (2003) reported that the enzymatic system implicated in the reduction of metmyoglobin and the reactions involved in the formation of this pigment could be disturbed by the application of HHP. These authors stored their samples in polyethylene that is a high gaseous permeability film. It must be remarked that in the present work, the samples were vacuum packaged in low permeability films; therefore, the decrease in $\mathrm{a}^{*}$ values during storage time was less notorious than in cases where samples have been stored in high gaseous permeability films (Jung et al. 2003) reaching $\mathrm{a}^{*}<9$ or in HHP-treated samples in contact with oxygen $\left(\mathrm{a}^{*}<6\right)($ Carlez et al. 1995).

Obtained results showed that higher pressures led to higher values of $\mathrm{L}^{*}$ and lower values of $\mathrm{a}^{*}$; however, in all the tested cases, the obtained $\mathrm{a}^{*}$ values for different conditions were in the range between 14.72 and 21.85 , being $\mathrm{a}^{*}>14$, suitable for consumers (Zamora and Zaritzky 1987).

\section{Lipid Oxidation}

Lipid oxidation during refrigerated storage at $0{ }^{\circ} \mathrm{C}$ was analyzed in the samples dipped in the preservative solutions ( $\mathrm{S} 1$ or S2) and then treated at 400 or $600 \mathrm{MPa}$ and on meat samples without any treatment (control).

TBARS values of untreated fresh samples during refrigerated storage changed from $0.080 \pm 0.005$ to $0.235 \pm 0.002 \mathrm{mg}$ MDA/kg meat after 6 weeks (Fig. 1a).

Storage time significantly influenced $(P<0.05)$ TBARS values, increasing over time (Fig. $1 \mathrm{a}-\mathrm{c}$ ); however, in all cases the values remained below the detection limit of rancid meat products $(<1 \mathrm{mg} \mathrm{MDA} / \mathrm{kg}$ ) given by Boles and Parrish (1990).

The application of HHP significantly increased $(P<0.05)$ TBARS index, observing higher values at $600 \mathrm{MPa}$ than at $400 \mathrm{MPa}$. However, the values obtained after refrigerated
Table 4 Color parameter a* of meat samples in function to the dipping solution (S1 and S2) and high pressures (400 and $600 \mathrm{MPa})$ during refrigerated storage at $0{ }^{\circ} \mathrm{C}$

\begin{tabular}{llllll}
\hline $\mathrm{a}^{*}$ & \multicolumn{2}{l}{$400 \mathrm{MPa}$} & & $600 \mathrm{MPa}$ & \\
\cline { 2 - 3 } \cline { 5 - 6 } Time (weeks) & $\mathrm{S} 1$ & $\mathrm{~S} 2$ & $\mathrm{~S} 1$ & $\mathrm{~S} 2$ \\
\hline 0 & $19.07 \pm 0.26^{\mathrm{c}, \mathrm{A}}$ & $21.85 \pm 0.81^{\mathrm{c}, \mathrm{B}}$ & & $19.31 \pm 1.04^{\mathrm{d}, \mathrm{A}}$ & $20.09 \pm 0.51^{\mathrm{c}, \mathrm{A}, \mathrm{B}}$ \\
1 & $17.50 \pm 0.14^{\mathrm{a}, \mathrm{A}}$ & $19.09 \pm 0.47^{\mathrm{a}, \mathrm{B}}$ & & $17.58 \pm 0.76^{\mathrm{b}, \mathrm{c}, \mathrm{d}, \mathrm{A}, \mathrm{B}}$ & $18.61 \pm 0.44^{\mathrm{b}, \mathrm{B}}$ \\
2 & $18.90 \pm 0.44^{\mathrm{c}, \mathrm{A}, \mathrm{B}}$ & $19.74 \pm 0.60^{\mathrm{a}, \mathrm{b}, \mathrm{B}}$ & & $17.74 \pm 0.69^{\mathrm{b}, \mathrm{c}, \mathrm{d}, \mathrm{A}}$ & $17.26 \pm 0.42^{\mathrm{a}, \mathrm{A}}$ \\
3 & $18.85 \pm 0.15^{\mathrm{b}, \mathrm{c}, \mathrm{B}}$ & $20.29 \pm 0.43^{\mathrm{a}, \mathrm{b}, \mathrm{c}, \mathrm{C}}$ & & $15.79 \pm 0.52^{\mathrm{a}, \mathrm{b}, \mathrm{A}}$ & $18.74 \pm 0.12^{\mathrm{b}, \mathrm{B}}$ \\
4 & $18.27 \pm 0.30^{\mathrm{b}, \mathrm{c}, \mathrm{C}}$ & $19.68 \pm 0.17^{\mathrm{a}, \mathrm{b}, \mathrm{B}}$ & & $14.72 \pm 0.16^{\mathrm{a}, \mathrm{A}}$ & $17.22 \pm 0.31^{\mathrm{a}, \mathrm{B}}$ \\
5 & $19.00 \pm 0.04^{\mathrm{c}, \mathrm{B}}$ & $21.53 \pm 0.87^{\mathrm{c}, \mathrm{C}}$ & & $16.56 \pm 0.74^{\mathrm{a}, \mathrm{b}, \mathrm{c}, \mathrm{A}}$ & $17.47 \pm 0.22^{\mathrm{a}, \mathrm{A}, \mathrm{B}}$ \\
6 & $17.59 \pm 0.30^{\mathrm{b}, \mathrm{A}}$ & $21.26 \pm 0.20^{\mathrm{b}, \mathrm{c}, \mathrm{B}}$ & & $18.06 \pm 1.00^{\mathrm{c}, \mathrm{d}, \mathrm{A}}$ & $18.86 \pm 0.36^{\mathrm{b}, \mathrm{B}}$ \\
\hline
\end{tabular}

Values are means $\pm \mathrm{SD}$

a-d: averages with different letters in the same column are different $(p<0.05)$

A-D: averages with different letters in the same row are different $(p<0.05)$ 
storage were below the limit of rancidity detection for such products, being therefore suitable for consumption (Fig. $1 \mathrm{~b}$,

c). Cheah and Ledward (1996) reported that high pressures
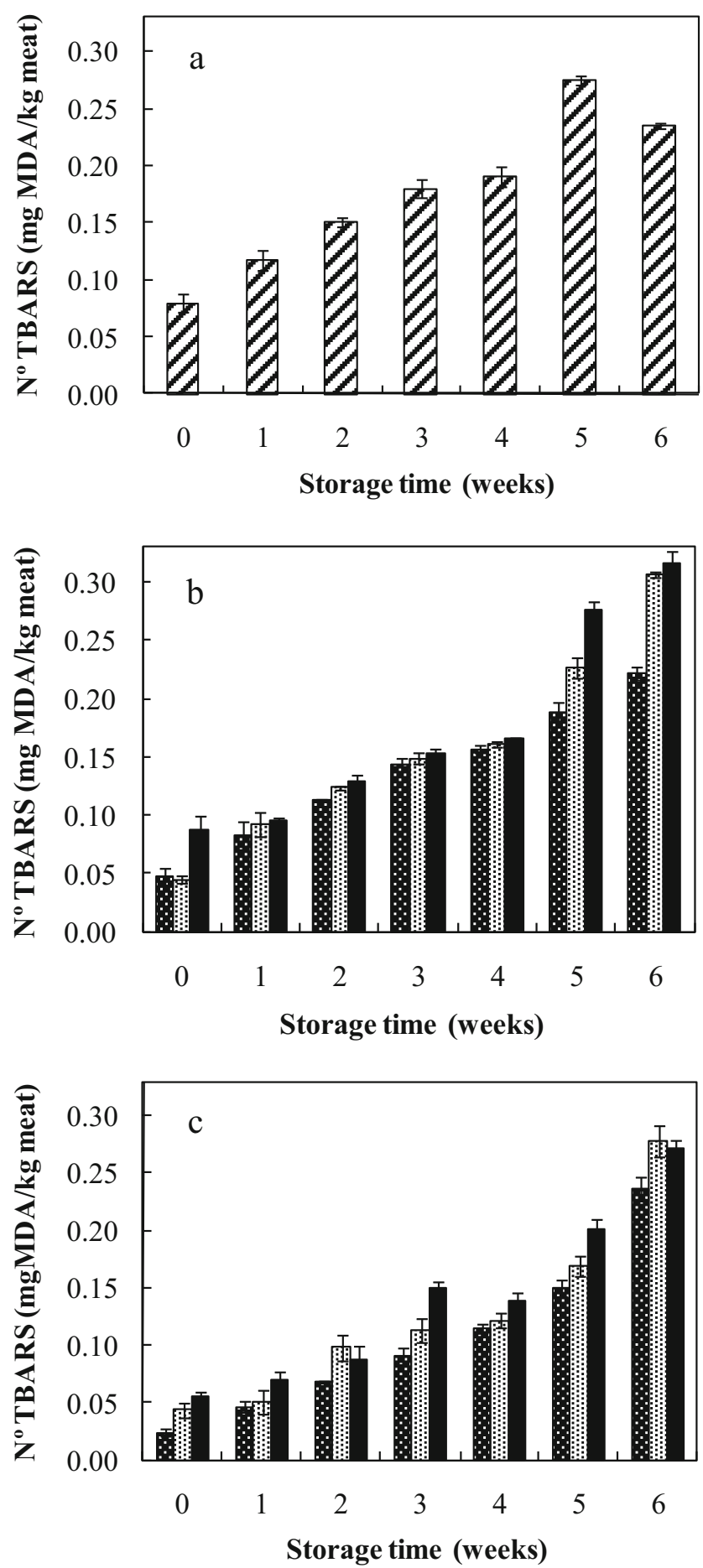

Fig. 1 a Lipid oxidation in untreated beef during refrigerated storage at $0{ }^{\circ} \mathrm{C}$ ). b, c Effect of HHP on lipid oxidation in beef samples dipped in b solution $\mathrm{S} 1$ and $\mathbf{c}$ solution $\mathrm{S} 2$, during refrigerated storage at $0{ }^{\circ} \mathrm{C}$. ( beef immersed in solution S1 or S2 without HHP. Beef immersed in solution S1 or S2 and treated with $400 \mathrm{MPa}$ (), or $600 \mathrm{MPa}$ (). Vertical bars indicate standard deviations decreased oxidative stability of meat. Ma et al. (2007) and McArdle et al. (2010) informed an increase in TBARS values in beef (Longissimus dorsi) treated at pressures $\geq 400 \mathrm{MPa}$ compared to fresh meat.

The preservative solutions significantly influenced $(P<0.05)$ TBARS values. The samples immersed in S1 solution presented higher TBARS values, and this may be due to the lower concentration of nitrite in the product. According to Freybler et al. (1993) and MacDonald et al. (1980), sodium nitrite has a stabilizing effect over lipid oxidation in meat.

Andrés et al. (2004) reported that high pressure may initiate the formation of radicals that could promote lipid oxidation and meat pigments deterioration. He et al. (2012) stated that phospholipids are mainly altered when samples were treated at $350 \mathrm{MPa}\left(20^{\circ} \mathrm{C}, 20 \mathrm{~min}\right)$. In addition, Carballo et al. (1997) showed that HPP favored the rupture of adipocytes in beef and that antioxidant enzymes are possibly affected by HPP.

\section{Microbial Counts}

During refrigerated storage at $0{ }^{\circ} \mathrm{C}$, growth of fungi, yeasts, and psychrotrophic bacteria in meat samples subjected to 400 and $600 \mathrm{MPa}$ was not observed. In fresh meat, the predominant flora was constituted by lactic acid and mesophilic bacteria presenting an initial microbial load of 5 and $3 \log \mathrm{CFU} / \mathrm{g}$, respectively.

Microbial counts in control samples, since the first week of refrigerated storage at $0{ }^{\circ} \mathrm{C}$ (Fig. 2a-d), exceeded the values (CFU/g meat) allowed under the Argentine regulations. Argentine Food Code (Article 255bis (res 712, 25/4/85) 2017b and Article 286) 2017a establishes the following microbiological requirements: mesophilic bacteria (counts at $\left.35^{\circ} \mathrm{C}\right) \leq 10^{6} \mathrm{CFU} / \mathrm{g}$, Enterobacteriaceae, $\leq 100 \mathrm{CFU} / \mathrm{g}$, fungi and yeasts $\leq 10^{3} \mathrm{CFU} / \mathrm{g}$, not presenting a limit for lactic acid bacteria. These values can be considered as a reference for the chemical pre-treated and HHP beef product.

In contrast, samples immersed in S1 solution and treated at $400 \mathrm{MPa}$ showed counts of mesophilic bacteria $<2 \log \mathrm{CFU} / \mathrm{g}$ during the first 3 weeks of storage. After the fourth week, counts were close to $4 \log \mathrm{CFU} / \mathrm{g}$ increasing approximately one $\log$ cycle in the fifth week. In the case of lactic acid bacteria (LAB) after the fourth week, counts were close to 3 $\log \mathrm{CFU} / \mathrm{g}$. For samples treated at $600 \mathrm{MPa}$, growth of mesophilic bacteria was observed after the fifth week while growth of lactic acid bacteria occurred after the sixth week. The samples immersed in the S2 solution presented counts of $\mathrm{LAB}<2 \log \mathrm{CFU} / \mathrm{g}$ for both pressures and growth of mesophilic bacteria after the fifth week for samples subjected to $400 \mathrm{MPa}$ and after the sixth week in those treated at $600 \mathrm{MPa}$.

The samples immersed in S2 solution, which contained higher $\mathrm{NaCl}$ concentration, maintained the microbiological stability for longer storage times; this may be attributed to 
Fig. 2 Comparison of microbial growth in beef samples without any treatment (fresh beef) during refrigerated storage at $0{ }^{\circ} \mathrm{C}(\mathrm{O})$ with samples immersed in solution S1 $(\square)$ or S2 $(\Delta)$ (before HHP treatment) and then submitted to $400 \mathrm{MPa}(\mathbf{a}, \mathbf{b})$; $600 \mathrm{MPa}$ (c,d), during refrigerated storage at $0{ }^{\circ} \mathrm{C}$. (a,c) mesophilic bacteria; (b,d) lactic acid bacteria. Vertical bars indicate standard deviations
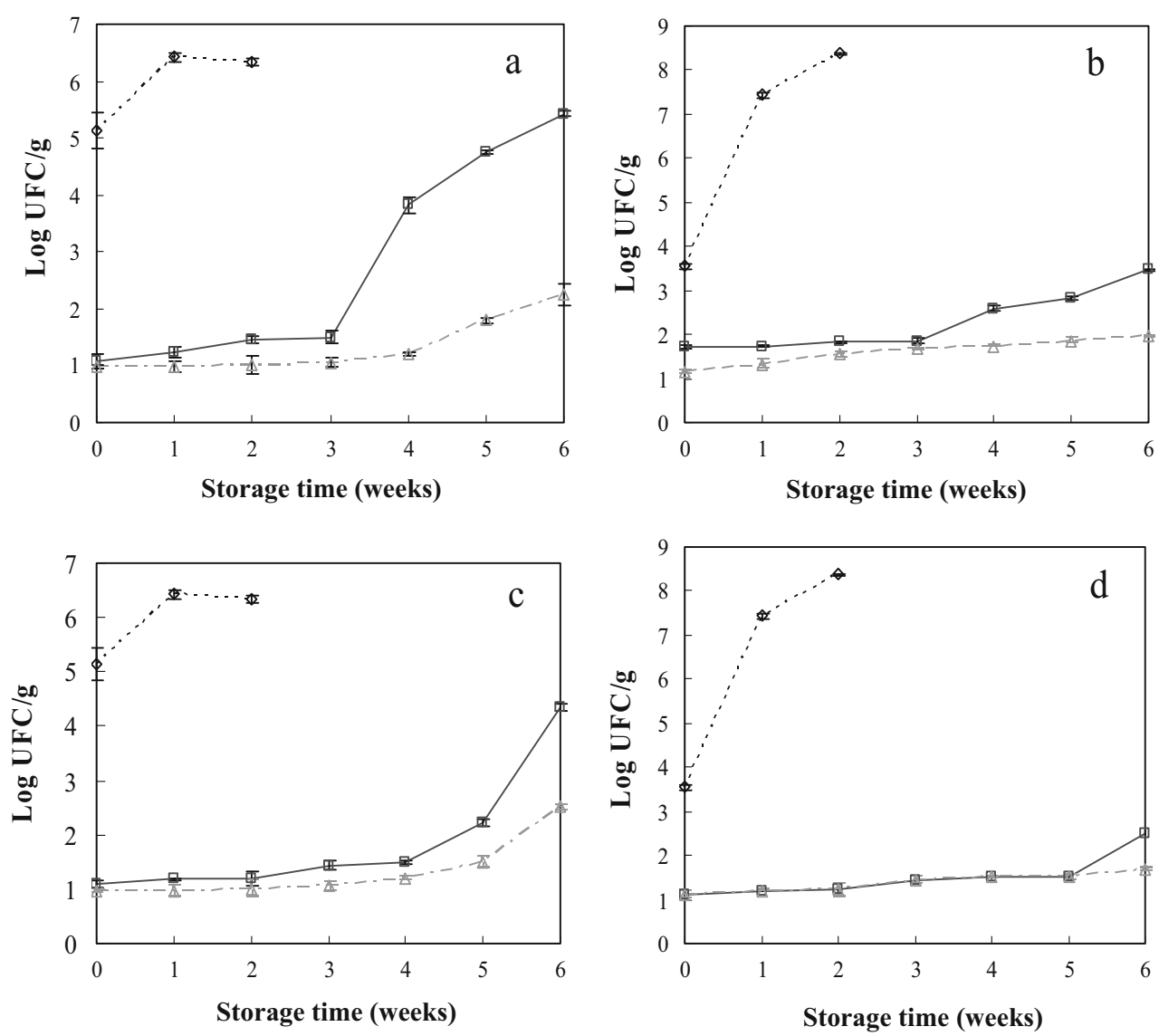

the bacteriostatic effect produced by both $\mathrm{NaCl}$ and $\mathrm{NaNO}_{2}$ which, as explained previously, increases the diffusion rate into the meat tissue with increasing $\mathrm{NaCl}$ concentration. Benedict (1980) and Tompkin (2005) found that nitrite has a bacteriostatic effect and in combination with salt inhibits food spoilage bacteria. Nitrous acid, which is in chemical equilibrium with nitrite in acid medium, has been shown to be reactive with several bacterial protein groups associated with cellular energy metabolism (Morita et al. 2004; Woods et al. 1981) or with membrane permeability (Buchman and Hansen 1987; Cammack et al. 1999).

In samples subjected to HHP, growth of enterobacteria during storage was not observed.

The inactivation of bacteria is ascribed to various types of damage accumulating inside the cell. After pressurization, structural and morphological changes inside the cells are observed (Bajovic et al. 2012). HPP can disrupt the cell membrane integrity decreasing the membrane fluidity and denaturing membrane bound proteins (Tao et al. 2014 and Rivalain et al. 2010). The pressure resistance of bacterial cells in the range 300-600 MPa depends on the species of bacteria and the food system involved. Generally, Gram-positive bacteria such as lactobacillus are more resistant to pressure than Gramnegative bacteria, molds, and yeasts (Cheftel 1995, FonbergBroczek et al. 2005 and Pilavtepe-Çelik et al. 2008).

\section{Conclusions}

A high-pressure treated beef product was developed by applying a chemical pre-treatment process of immersion in a preservative solution followed by high hydrostatic pressure. The product maintained conditions suitable for consumption for a longer time than fresh beef, with appropriate sensory attributes and a significantly higher storage life than the untreated beef product.

Color problems on HHP beef products were diminished by applying a short chemical pre-treatment by immersing the samples in a solution containing sodium chloride and sodium nitrite, salts that are commonly applied in the curing process.

It was found that varying the $\mathrm{NaCl}$ concentration in the dipping solution affects the color parameters and microbiological stability after treatment with HHP using both pressures (400 and $600 \mathrm{MPa}$ ); however, redness was visually acceptable (a* $>14)$. Control samples (fresh meat without any treatment) lost their safe condition during the second week, due to high microbial counts. The samples immersed in the solution S2 (containing $60 \mathrm{~g} \mathrm{NaCl} / \mathrm{L}$ ) that leads to a concentration in the tissue of $5.24 \mathrm{~g} \mathrm{NaCl} / 100 \mathrm{~g}$ tissue, when subjected to both 400 and $600 \mathrm{MPa}$ maintained their microbiological stability (based on mesophilic counts) at least for 6 weeks. In contrast, samples treated with S1 solution containing a lower amount of 
$\mathrm{NaCl}(30 \mathrm{~g} \mathrm{NaCl} / \mathrm{L})$ corresponding to $1.95 \mathrm{~g} \mathrm{NaCl} / 100 \mathrm{~g}$ tissue had lower storage life: 4 and 5 weeks at 400 and $600 \mathrm{MPa}$, respectively.

The shelf life of the high-pressure treated beef product can be regulated by modifying the saline concentration in the tissue adjusting the formulation of the dipping solution and immersion times. This work will be continued by testing the effect of pressure, salt content, and refrigerated storage time on the inhibition of pathogenic microorganisms inoculated in meat samples such as L. monocytogenes.

Acknowledgments The authors gratefully acknowledge the financial support given by National University of La Plata, Consejo Nacional de Investigaciones Científicas y Tecnológicas (CONICET), and ANPCYT from ARGENTINA. Also the contribution of the Project "Safety improvement and shelf life extension of fresh and cooked beef and mutton products applying non-thermal technologies" (Argentina-China) coordinated by Dr. S. Vaudagna is also acknowledged.

\section{References}

Argentine Food Code. (2017a). Chapter 6. Alimentos cárneos y afines. Artículo 286 (Resolución Conjunta SPyRS y SAGPyA N 104/

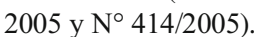

Argentine Food Code. (2017b). Capítulo 6. Alimentos cárneos y afines. Artículo 255bis (Res 712, 25.4.85).

Andrés, A. I., Møller, J. K. S., Adamsen, C. E., \& Skibsted, L. H. (2004). High pressure treatment of dry-cured Iberian ham. Effect on radical formation, lipid oxidation and colour. European Food Research and Technology, 219(3), 205-210.

AOAC. (1980). Official methods of analysis (13th ed.p. 1018). Washington DC: Association of Official Analytical Chemists.

Bajovic, B., Bolumar, T., \& Heinz, V. (2012). Quality considerations with high pressure processing of fresh and value added meat products. Meat Science, 92, 280-289.

Bak, K. H., Lindahl, G., Karlsson, A. H., Lloret, E., Ferrini, G., Arnau, J., et al. (2012). High pressure effect on the color of minced cured restructured ham at different levels of drying, $\mathrm{pH}$, and $\mathrm{NaCl}$. Meat Science, 90, 690-696.

Beltran, E., Pla, R., Yuste, J., \& Mor-Mur, M. (2003). Lipid oxidation of pressurized and cooked chicken: role of sodium chloride and mechanical processing on TBARS and hexanal values. Meat Science, 64(1), 19-25.

Benedict, R. C. (1980). Biochemical basis for nitrite-inhibition of Clostridium botulinum in cured meat. Journal of Food Protection, 43, 877-891.

Boles, J. A., \& Parrish Jr., F. C. (1990). Sensory and chemical characteristics of precooked microwave-reheatable pork roasts. Journal of Food Science, 55, 618-620.

Botsoglou, N. A., Fletouris, D. J., Papageorgiou, G. E., Vassilopoulos, V. N., Mantis, A. J., \& Trakatellis, A. G. (1994). Rapid, sensitive and specific thiobarbituric acid method for measuring lipid peroxidation in animal tissue, food and feedstuff samples. Journal of Agricultural and Food Chemistry, 42, 1931-1937.

Buchman, G. W., \& Hansen, N. (1987). Modification of membrane sulflhydryl groups in bacteriostatic action of nitrite. Applied and Environmental Microbiology, 53, 79.

Cammack, R., Joannou, C. L., Cui, X. Y., Torres Martinez, C., Maraj, S. R., \& Hughes, M. N. (1999). Nitrite and nitrosyl compounds in food preservation. Biochimica et Biophysica Acta, 1411, 475-488.
Campus, M., Flores, M., Martinez, A., \& Toldrá, F. (2008). Effect of high pressure treatment on colour, microbial and chemical characteristics of dry cured loin. Meat Science, 80(4), 1174-1181.

Carballo, J., Fernandez, P., Carrascosa, A. V., Solas, M. T., \& JiménezColmenero, F. (1997). Characteristics of low and high-fat beef patties: effect of high hydrostatic pressure. Journal of Food Protection, $60(1), 48-53$.

Carlez, A., Veciana-Nogues, T., \& Cheftel, J. C. (1995). Changes in colour and myoglobin of minced beef meat due to high pressure processing. Lebensmittel-Wissenschaft und-Technologie, 28, 528538.

Cheah, P. B., \& Ledward, D. A. (1996). High pressure effects on lipid oxidation in minced pork. Meat Science, 43, 123-134.

Cheftel, C. (1995). Review: high-pressure, microbial inactivation and food preservation. Food Science and Technology International, 1, 75 .

Cheftel, J. C., \& Culiol, J. (1997). Effect of high pressure on meat: a review. Meat Science, 46, 211-236.

Dotsch, M., Busch, J., Batenburg, M., Liem, G., Tareilus, E., Mueller, R., et al. (2009). Strategies to reduce sodium consumption: a food industry perspective. Critical Reviews in Food Science and Nutrition, $49,841-851$.

Duranton, F., Guillou, S., Simonin, H., Chéret, R., \& de Lamballerie, M. (2012). Combined use of high pressure and salt or sodium nitrite to control the growth of endogenous microflora in raw pork meat. Innovative Food Science and Emerging Technologies, 16(2012), 373-380.

FAO (1991). Guidelines for slaughtering meat cutting and further processing.

Ferrini, G., Comaposada, J., Arnau, J., \& Gou, P. (2012). Colour modification in a cured meat model dried by quick-dry-slice process and high pressure processed as a function of $\mathrm{NaCl}, \mathrm{KCl}, \mathrm{K}$-lactate and water contents. Innovative Food Science and Emerging Technologies, 13, 69-74.

Fonberg-Broczek, M., Windyga, B., Szczawiński, J., Szczawińska, M., Pietrzak, D., \& Prestamo, G. (2005). High pressure processing for food safety. Acta Biochimica Polonica, 52(3), 721-724.

Freybler, L. A., Gray, J. I., Asghar, A., Booren, A. M., Pearson, A. M., \& Buckley, D. J. (1993). Nitrite stabilization of lipids in cured pork. Meat Science, 33, 85-96.

Giménez, B., Graiver, N., Califano, A., \& Zaritzky, N. (2015). Physicochemical characteristics and quality parameters of a beef product subjected to chemical preservatives and high hydrostatic pressure. Meat Science, 100, 179-188.

Goutefongea, R., Rampon, V., Nicolas, J., \& Dumont, J.P. (1995). Meat color changes under high pressure treatment. In: Proceeding of the 41st International Congress of Meat Science and Technology, 20-25 August 1995, San Antonio, Texas, Pages, 384-385.

Graiver, N., Pinotti, A., Califano, A., \& Zaritzky, N. (2006). Diffusion of sodium chloride in pork tissue. Journal of Food Engineering, 77, 910-918.

Gray, J. I., Gomaa, E. A., \& Buckley, D. J. (1996). Oxidative quality and shelf life of meats. Meat Science, 43, S111-S123.

Grigera, J. R., \& McCarthy, A. N. (2010). The behavior of the hydrophobic effect under pressure and protein denaturation. Biophysical Journal, 98, 1626-1631.

He, F., \& MacGregor, G. A. (2010). Reducing population salt intake worldwide: From evidence to implementation. Progress in Cardiovascular Diseases, 52, 363-382.

He, F. J., Burnier, M., \& MacGregor, G. A. (2011). Nutrition in cardiovascular disease: salt in hypertension and heart failure. European Heart Journal, 32(24), 3072-3083.

He, Z., Huang, Y., Li, H., Qin, G., Wang, T., \& Yang, J. (2012). Effect of high pressure treatment on the fatty acid composition of intramuscular lipid in pork. Meat Science, 90, 170-175. 
Hogan, E., Kelly, A. L., \& Sun, D. W. (2005). High pressure processing of foods: an overview. In S. Da-Wen (Ed.), Emerging Technologies for Food Processing (1st ed., pp. 3-32). Elsevier: Academic Press.

Jung, S., Ghoul, M., \& de Lamballerie-Anton, M. (2003). Influence of high pressure on the color and microbial quality of beef meat. Lebensmittel-Wissenschaft und-Technologie, 36(6), 625-631.

Keast, R. S. J., \& Breslin, P. A. S. (2002). An overview of binary tastetaste interactions. Food Quality and Preference, 14, 111-124.

Ma, H. J., Ledward, D. A., Zamri, A. I., Frazier, R. A., \& Zhou, G. H. (2007). Effects of high pressure/thermal treatment on lipid oxidation in beef \& chicken muscle. Food Chemistry, 104, 1575-1579.

MacDonald, B., Gray, J. L., \& Gibbins, L. N. (1980). Role of nitrite in cured meat flavor: Antioxidant role of nitrite. Journal of Food Science, 45, 893-897.

Marcos, B., Kerry, J. P., \& Mullen, A. M. (2010). High pressure induced changes on sarcoplasmic protein fraction and quality indicators. Meat Science, 85(1), 115-120.

McArdle, R., Marcos, B., Kerry, J. P., \& Mullen, A. (2010). Monitoring the effects of high pressure processing and temperature on selected beef quality attributes. Meat Science, 86, 629-634.

Morita, H., Yoshikawa, H., Suzuki, T., Hisamatsu, S., Kato, Y., Sakata, R., et al. (2004). Antimicrobial action against verotoxigenic Escherichia coli O157:H7 of nitric oxide derived from sodium nitrite. Bioscience, Biotechnology, and Biochemistry, 68, 1027-1034.

Mor-Mur, M. (2010). Alimentos tratados por alta presión. Aspectos nutricionales. Actividad Dietética, 14(2), 53-58.

Pilavtepe-Çelik, M., Balaban, M. O., Alpas, H., \& Yousef, A. E. (2008). Image analysis based quantification of bacterial volume change with high hydrostatic pressure. Journal of Food Science, 73, M423M429.

Rivalain, N., Roquain, J., \& Demazeau, G. (2010). Development of high hydrostatic pressure in biosciences: pressure effect on biological structures and potential applications in biotechnologies. Biotechnology Advances, 28, 659-672.

Rubio, B., Martinez, B., Garcia-Cachan, M. D., Rovira, J., \& Jaime, I. (2007). Effect of high pressure preservation on the quality of dry cured beef "Cecina de Leon". Innovation Food Science and Emerging Technologies, 8(7), 102-110.

Szerman, N., Barrio, Y., Schroeder, B., Martinez, P., Sancho, A. M., Sanow, C., et al. (2011). Effect of high hydrostatic pressure treatments on physicochemical properties, microbial quality and sensory attributes of beef carpaccio. In: 1th International Congress on Engineering and Food (ICEF11). Procedia Food Science, 1, 854 861.

Tao, Y., Sun, D.W., Hogan, E., \& Kelly, A. L. (2014). Chapter 1 - Highpressure processing of foods: an overview. Emerging Technologies for Food Processing (Second Edition), Pages 3-24.

Tompkin, R. B. (2005). Nitrite. In P. M. Davidson, J. N. Sofos, \& A. L. Branen (Eds.), Antimicrobials in food (3rd ed.). Boca Raton: CRC Press, Taylor \& Francis Group.

Ueno, Y., Ikeuchi, Y., \& Suzuki, A. (1999). Effects of high pressure treatments on intramuscular connective tissue. Meat Science, 52, $143-150$.

USDA. (2016).United States Department of Agriculture Agricultural Research Service. National Nutrient Database for Standard Reference. Full Report (All Nutrients) 13972, Beef, chuck eye roast, boneless, America's Beef Roast, separable lean only, trimmed to 0" fat, all grades, raw.

USDA-FSIS (1999). Food Ingredients and Sources of Radiation Listed or Approved for Use in the Production of Meat and Poultry Products; Final Rule. Subpart C-424.21. Use of Food Ingredients and Sources of Radiation. Code of Federal Regulations, title 9, vol. 64, part 424. Office of Federal Register, National Archives and Records, GSA, Washington, DC,. 72185-72186 (Chapter III).

Woods, L. F. J., Wood, J. M., \& Gibbs, P. A. (1981). The involvement of nitric oxide in the inhibition of the phosphoroclastic system in Clostridium sporogenes by sodium nitrite. Journal of General Microbiology, 125, 399-406.

Zamora, M. C., \& Zaritzky, N. E. (1987). Potassium sorbate inhibition of microorganisms owin in refrigerated beef. Journal of Food Science, $52,257$. 